\title{
A novel suspension-floating-circulating fluidized combustion technology for coal slurry
}

\author{
Yi Wang ${ }^{1} \cdot$ Maoyong $\mathrm{Cao}^{1} \cdot$ Zenghui Wang $^{2} \cdot \mathrm{Lu} \mathrm{Wei}^{1} \cdot$ Shuping $\mathrm{Zhao}^{3}$
}

Received: 11 January 2015/Revised: 28 April 2015/Accepted: 28 July 2015/Published online: 18 February 2016

(C) The Author(s) 2016. This article is published with open access at Springerlink.com

\begin{abstract}
A novel suspension-floating-circulating fluidized combustion technology is proposed for burning coal slurry fuel in traditional circulating fluidized bed boilers (CFBB). This technology can solve some existing problems in largecapacity CFBB burning coal slurry. The principles of the suspension-floating-circulating fluidized combustion technology were introduced in detail in this paper. A $130 \mathrm{t} / \mathrm{h}$ CFBB was retrofitted based on the technology, and the retrofitted system mainly includes a long-distance transport sub-system, a bed-material conveying sub-system with a wind-seal device invented by the authors, a superheater thermoregulation device using a novel temperature regulator, a return loop fluidization facility, and a pneumatic ash conveying sub-system with sealed pump. The achieved performance of the retrofitted CFBB shows that the thermal efficiency is $89.83 \%$, the combustion efficiency is $96.24 \%$, and the blending proportion of slurry is $94 \%$.
\end{abstract}

Keywords Suspension-floating-circulating fluidized $\cdot$ Coal slurry $\cdot$ Combustion technology $\cdot$ CFBB

\section{Introduction}

Coal slurry is a by-production of coal washing plant. The surface of slurry is viscous with the water content of 25 to 40 percent and 80 percent of solid coal particles are less than $3 \mathrm{~mm}$ in diameter (Cao et al. 2009; Liu et al. 2012), so it is difficult to achieve long distance carriage. As a result, a lot of coal slurry has been stacking in the air for a long time, they not only encroach a great quantity of land but also cause serious damage to ecological environment.

Extensive utilization of low-heat value fuel is important in China. Coal slurry belongs to the low-heat value fuel,

Yi Wang

skdwangyi@163.com

1 Shandong University of Science and Technology, Qingdao 266590, China

2 Department of Electrical and Mining Engineering, University of South Africa, Pretoria 1710, Florida, South Africa

3 Shandong Energy Feicheng Mining Group Co. LTD Baizhuang Mine, Feicheng 271600, China whose combustion technology has been studied extensively in recent years (Chi et al. 2001; Tang et al. 2007; Wu et al. 2009; Bo et al. 2013; Ni et al. 2014; Shu and Zhang 2014). The results reveal that appropriately retrofitted circulating fluidized bed (CFB) boilers of less than $75 \mathrm{t} / \mathrm{h}$ capacity can be successfully applied in burning coal slurry, but it is still difficult to solve the problem of coal slurry large-scale application. So researches are paying increasing attention to CFBB with capacities larger than $75 \mathrm{t} / \mathrm{h}$. While most of the previous researches only focused on the atomization combustion (Jakobs et al. 2012; Daviault et al. 2012; Ma et al. 2013). It was reported that a retrofitted $130 \mathrm{t} / \mathrm{h}$ CFBB with atomization combustion had achieved boiler thermal efficiency of $90.3 \%$ and combustion efficiency of $99 \%$ (Cheng et al. 2008). A retrofitted $440 \mathrm{t} / \mathrm{h}$ CFBB with atomization combustion ( $\mathrm{Yu}$ et al. 2008; Qu et al. 2010) has achieved a boiler thermal efficiency of $89 \%$, but it only blended $25 \%$ coal slurry. From these applications, it can be concluded that large-scale CFB boilers have difficulties in achieving high boiler thermal efficiency, combustion efficiency and blending proportion in burning coal slurry. The coal slurry atomization combustion has some 
problems as follows: (1) coal slurry needs special handling, (2) the high-pressure atomization devices are expensive and easy to be blocked, (3) the life of the feeding hose is short, (4) slagging easily appear at the bottom of the fluidized bed, (5) fly ash carbon content is high, and (6) boiler efficiency is low, etc.

The combustion mode of the feeding slurry from the top of the boiler has been also studied in recent years (Gagarin and Gyu'maliev 2009; Wang et al. 2010), and it is considered to have good prospect for development. A $75 \mathrm{t} / \mathrm{h}$ CFB boiler with the combustion have achieved a boiler thermal efficiency of $86 \%$ and an average combustion efficiency of $95 \%$ after retrofitted by blending $70 \%$ coal slurry (Ji and Wang 2007). However, the application results showed that there were still some problems that need to be solved:

(1) The blending proportion of slurry is usually less than $70 \%$;

(2) The over-temperature phenomenon of platen superheater is serious causes explosion easily;

(3) The temperature of returned fuel is high which can easily cause coking in the return feeder;

(4) The high temperature ash goes into the coal conduit easily that makes the conveying belt aging;

(5) The contentration of sulfur and nitrogen in the fly ash is high;

(6) The loss and failure rate of the ash conveying system are high.

These problems often lead to the lower boiler thermal efficiency, combustion efficiency and blending proportion in burning coal slurry, therefore preventing the suspension combustion technology from being applied to the larger CFB boiler.

Based on the large-scale CFB boilers combustion technology especially on the existing problems, a new type of suspension-floating-circulating fluidized combustion technology is necessary and presented in this paper. The main principles and design concepts of the technology are introduced in detail in the following section, and the results of the practical application of a $130 \mathrm{t} / \mathrm{h} \mathrm{CFBB}$, which is used in a power plant, are presented. Finally, the conclusion is given.

\section{Suspension-floating-circulating fluidized combustion technology}

High concentration coal slurry is used as boiler fuel. Coal gangue is used as bed material. The structure of the boiler system using suspension-floating-circulating fluidized combustion technology is shown in Fig. 1.

The boiler mainly includes the furnace, coal slurry feeding system, the bed-material conveying system, steam temperature regulated system, a cyclone separator and an $\mathrm{U}$ return feeder, an ash conveying system, a primary air and secondary air system and bottom slag cooler, etc. Compared with atomization combustion technology, slurry atomization, filtering and high pressure feeding devices are not needed, so the boiler using the new technology, which doesn't require extensive retrofit and the reliability can be greatly improved.

As shown in Fig. 2, the principles of the new technology are as follows. Some of the high density and differentsize coal gangue granules are conveyed to the bottom of the fluidized bed by the bed-material conveying system to ensure the bed pressure of the CFB. The high concentration slurry from the coal washery with a moisture content of about $30 \%$ is delivered to the top of the furnace by a feeding system, and fallen into the furnace along the slurry pipeline. The falling coal slurry meet the high temperature (900-960 ${ }^{\circ} \mathrm{C}$ ) of furnace and experience drying, agglomeration, volatilize, thermal explosion, burning and falling stages. This process is the suspension combustion. Through the suspension combustion, big slurry blocks break into different-size blocks. Asymmetrical secondary air is designed to flow on the opposite sides of the furnace wall. Under the influence, the falling coal slurry blocks rotate, thus its falling time and path are prolonged to make the blocks finish suspension combustion. After the suspension combustion, the unburned blocks fall on the CFB surface, float above the coal gangue, and finish the floating combustion. With the bed material fluidization period, some unburned blocks will experience fragmenting, abrasion, crushing, aggregation, rising and sinking, blowing away and burn out. This is the internal circulating fluidized combustion process. The other parts of unburned blocks and the flue gas enter the cyclone separator for gassolid separation together. When the separated gas enters the rear smoke channel, the separated ash will be transported to the ash warehouse after the electrostatic precipitator. While the separated solid including the bed material and unburned blocks will return to the CFB via the return feeder to go to the next combustion cycle. This process is the external circulating fluidized combustion. The coal slurry experiences suspension-floating-circulating fluidized combustion, and eventually achieves efficient combustion.

In order to ensure the combustion efficiency, and improve the blending proportion of slurry and the reliability of the boiler, the CFBB's auxiliary system has been designed. It mainly includes a long distance feeding system with plunger pump, a bed-material conveying system with the new sealing device, a three levels of superheater thermoregulation device with two first-grade desuperheaters, a cyclone separator and U return feeder, a low pressure pneumatic ash conveying system with material sealed 


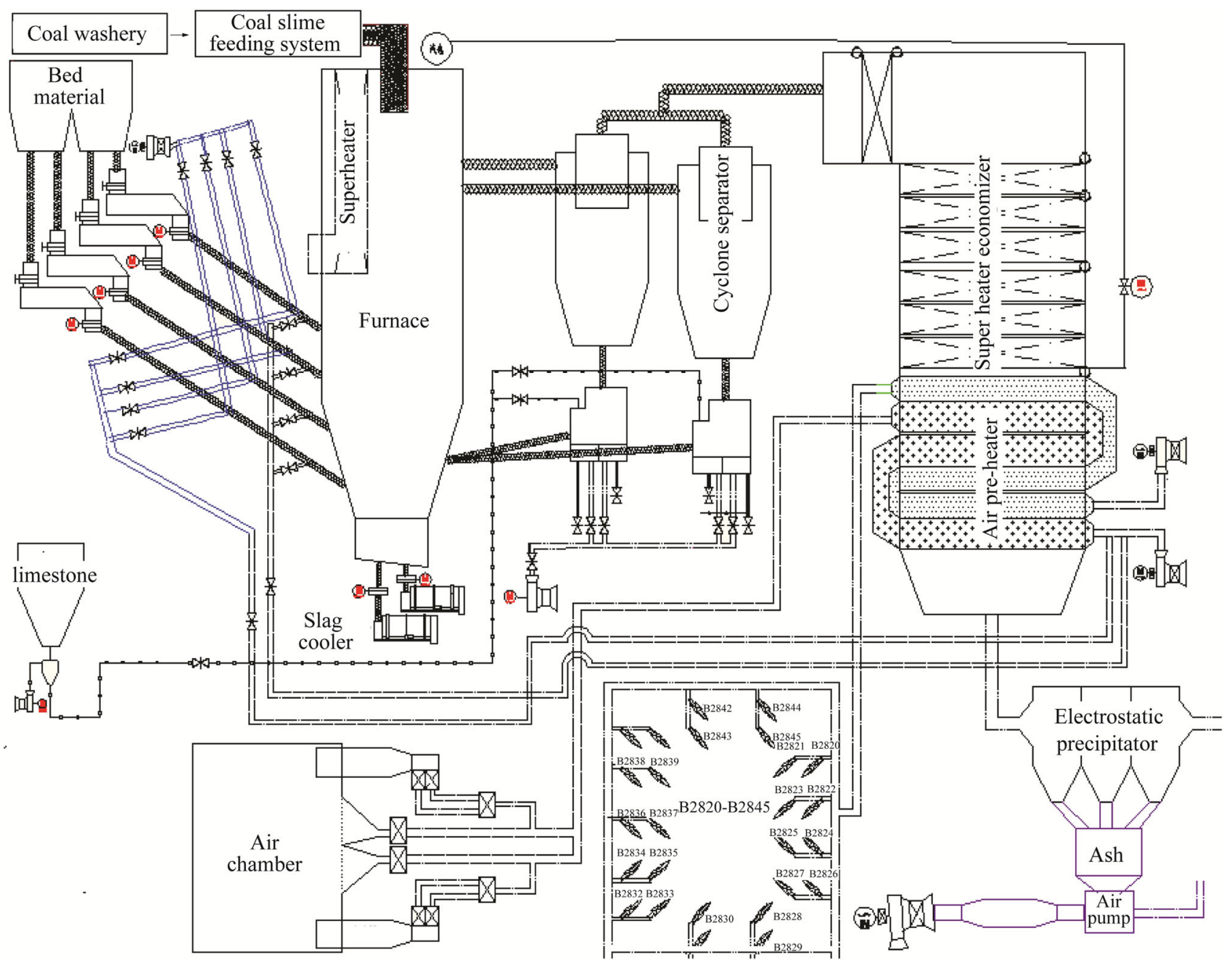

Fig. 1 Structure of the boiler system

pump and an asymmetrical secondary air system on both sides of the furnace.

The new technology has the following features. The blending proportion of coal slurry can reach $94 \%$ in the CFBB fuel; the coal slurry is fed to the top of furnace via pipeline directly, which eliminates the need of atomization and filtering systems in atomization combustion; and the high combustion temperature $\left(900-960{ }^{\circ} \mathrm{C}\right)$ can improve the burnout effect significantly and effectively control the coking and $\mathrm{N}_{2} \mathrm{O}$ production; the new combustion technology can also solve many problems, such as the superheater over temperature, the conveying belt of bed material aging, high content of sulfur and nitrogen in ash, and returned fuel coking in the return feeder.

\subsection{Coal slurry feeding system}

Pipeline is the main method for conveying the coal slurry (Chen et al. 2009; Liu and Duan 2009). Long-distance pipeline transportation is the key of the coal slurry burning. The viscous material pipeline system (MNS pipeline transportation system) (Lu and Duan 2006) is used to convey the slurry. It could solve a series of technical problems in the long-distance pipeline transport, such as the slurry flow control, duct sealing vibration, pipes wear, pulping, storing, mixing, transporting, feeding and cleaning. It can achieve a transported process which is fully enclosed, steady, long-distance and non-polluting.

The structure of MNS is shown in Fig. 3. In the MNS, slurry is sent to the cache warehouse after pretreatment, then through overhaul gate, positive pressure feeder, double plunger pump, valve, and finally fed into the furnace via spiral feeder. The work ing process is controlled automatically by a programmable logic controller and a distributed control system.

The diameter of pipeline and the average velocity of coal slurry can be calculated by the formulas.

$\bar{V}<\sqrt[2-n]{R_{e} 8^{n-1} \rho^{-1} \eta D^{n}}$ 


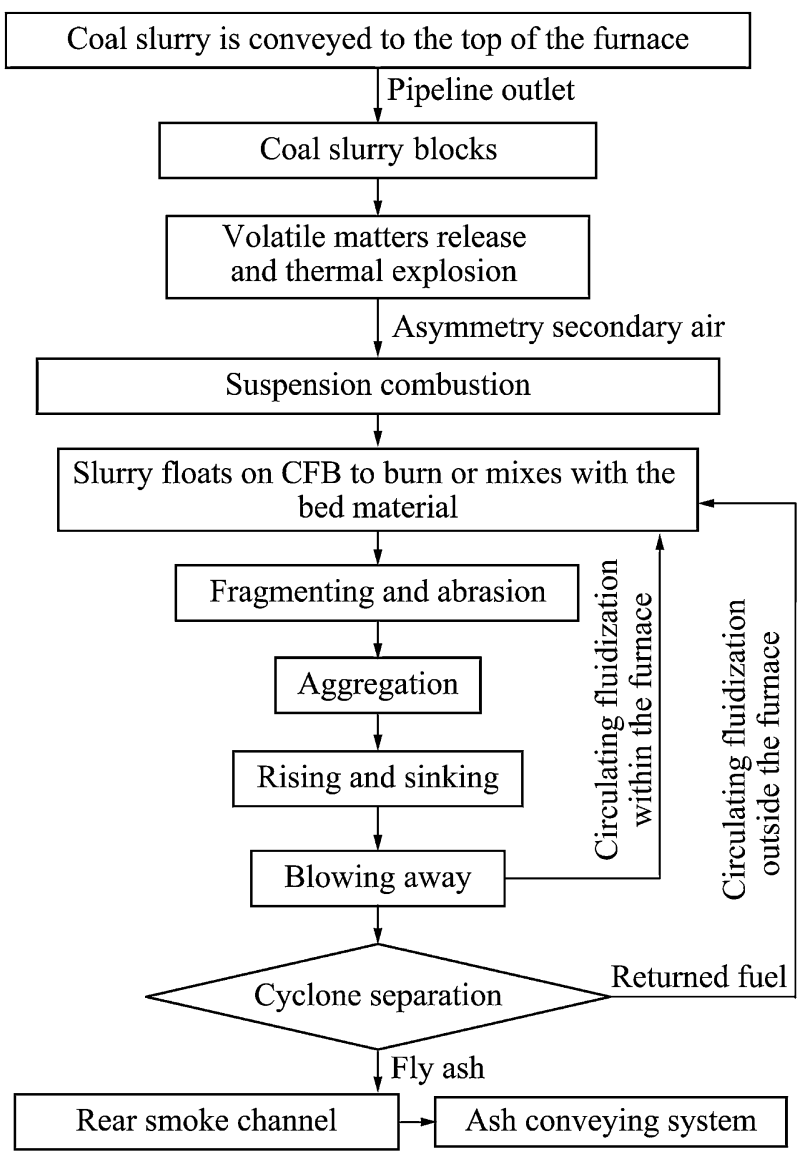

Fig. 2 Combustion process flowchart

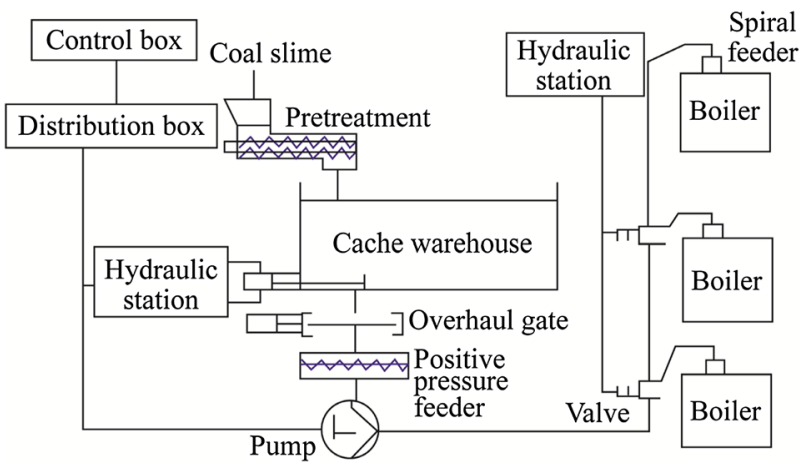

Fig. 3 MNS pipeline transportation process flowchart

$\bar{V}=\frac{4 Q}{\pi D^{2}}$

where, $R_{e}$ is the Reynolds number, $Q$ is the desired flow of the CFBB, $\rho$ is the density of coal slurry, $n$ and $\eta$ are rheological characteristic parameters, and $D$ is the internal diameter of the pipeline.

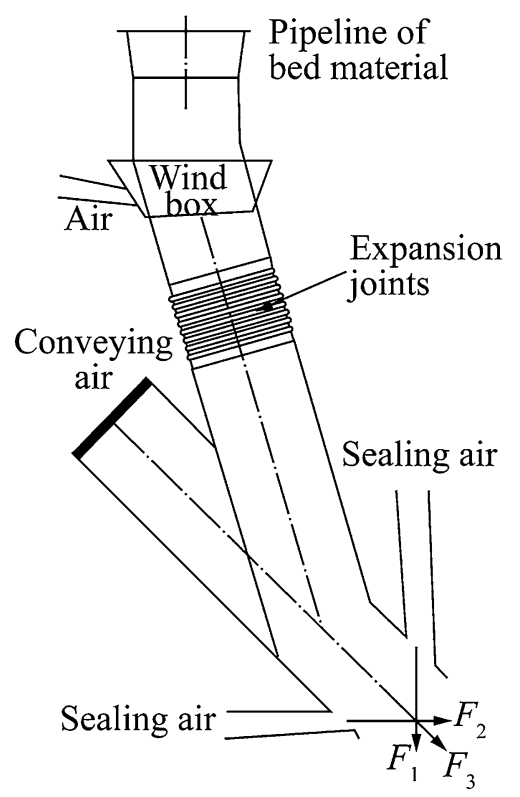

Fig. 4 Bed material conveying pipe structure

\subsection{Bed-material conveying system}

In the process of boiler start-up and operation, keeping a steady bed material height is very important for boiler safety. The bed material conveying system is designed based on the original coal conveying system of CFB boiler. Because the particles density and distribution size of bed material are higher than the coal particles, it easily causes blockage of the pipeline which used to transport the bed material. Moreover, when no bed material in the conveying pipe, the high temperature flue gas in the furnace returns enters to the pipe easily and then causes the conveying belt aging.

For these reasons, a new air sealing device is designed (Fig. 4). Two symmetrical sealing air pipes are set at the bottom of the conveying pipe. If the pressures of the sealing air are $F_{1}$ and $F_{2}$, then $F_{1}$ and $F_{2}$ form a joint force $F_{3} . F_{3}$ forms a resistance to prevent the high temperature flue gas. At the same time, the pressure of conveying air and $F_{3}$ form the push-pull effect in conveying pipe to solve the problem of pipe blockage.

The bed-material conveying system has the following merits. It can convey widely size bed material. The innovative sealed device can not only decrease the pipe blockage, but also prevent the high-temperature flue gas to prolong the life of the conveying belt.

\subsection{Furnace system design}

The furnace is the most important component in the suspension-floating-circulating fluidized combustion system. 
Materials enter into the furnace include fuel, bed material, desulfurizer and gas, etc. Meanwhile some solid materials and gases leave the furnace, including the ash at the bottom of furnace, recycled material and flue gas.

\subsubsection{Heat exchange law inside the furnace}

The heat exchange inside the furnace satisfies the following equations (Jiang and Xiao 2009).

$$
\begin{aligned}
& B_{j} Q_{1}^{R}=\phi B_{j}\left[X Q_{1 s}^{m}-\left(I_{m z}^{\prime \prime}-I_{z e}^{\prime \prime}\right) \frac{B_{s}}{B_{j}}-I_{m}^{\prime \prime}\right] \\
& B_{j} Q_{1}^{R}=K_{m} B_{j}^{m}\left(\theta_{m}^{\prime \prime}-t_{b}\right) \\
& Q_{1 s}^{m}=Q_{n e t, a r} \eta+\alpha_{m}^{\prime} I_{r k}^{\prime}+\alpha_{z}^{\prime} I_{l k}^{\prime}+\alpha_{p}^{\prime} I_{l k}^{\prime}
\end{aligned}
$$

where, $B_{j}$ is the fuel consumption, $\mathrm{kg} / \mathrm{s} ; Q_{1}^{R}$ is the heat of per kilogram of combustion product transferred to the heating surfaces and material in the furnace, $\mathrm{kJ} ; \phi$ is the coefficient of heat preservation; $Q_{1 s}^{m}$ is the effective value of heat that is released, $\mathrm{kJ} / \mathrm{kg} ; x$ is the share of effective value $Q_{1 s}^{m} ; I_{m z}^{\prime \prime}$ is the ash enthalpy at furnace exit, $\mathrm{kJ} / \mathrm{kg} ; I_{z e}^{\prime \prime}$ is the ash enthalpy at furnace inlet, $\mathrm{kJ} / \mathrm{kg} ; B_{s}$ is the amount of circulating ash, $\mathrm{kg} / \mathrm{s} ; I_{m}^{\prime \prime}$ is flue gas enthalpy at furnace exit, $\mathrm{kJ} / \mathrm{kg} ; k_{m}$ is the heat transfer coefficient of furnace, $\mathrm{kJ} /\left(\mathrm{m}^{2} \mathrm{~s}{ }^{\circ} \mathrm{C}\right) ; B_{j}^{m}$ is the heating surface area of furnace, $\mathrm{m}^{2} ; \theta_{m}^{\prime \prime}$ is the temperature at furnace exit, ${ }^{\circ} \mathrm{C} ; t_{b}$ is the tube wall temperature at the water wall, ${ }^{\circ} \mathrm{C} ; \alpha_{m}^{\prime}$ is the excess air coefficient at furnace exit, $\mathrm{kJ} / \mathrm{kg} ; \alpha_{z}^{\prime}$ is the excess air coefficient at return valve inlet; $I_{l k}^{\prime}$ is the cold air enthalpy, $\mathrm{kJ} / \mathrm{kg}$.

The equation of boiler thermal efficiency is as follows (Jiang and Xiao 2009).

$\gamma=100-\frac{Q_{2}+Q_{3}+Q_{4}+Q_{5}+Q_{6}+Q_{7}}{Q_{r}} \times 100 \%$

where, $\gamma$ is the boiler thermal efficiency; $Q_{2}$ is the exhaust smoke heat loss per kilogram fuel, $\mathrm{kJ} ; Q_{3}$ is the combustion heat loss of combustible gas per kilogram fuel, $\mathrm{kJ} ; Q_{4}$ is the solid incomplete combustion heat loss per kilogram fuel, $\mathrm{kJ} ; Q_{5}$ is the heat loss per kilogram fuel, $\mathrm{kJ} ; Q_{6}$ is the slag heat loss per kilogram fuel, $\mathrm{kJ} ; Q_{7}$ is the desulfurization heat loss per kilogram fuel, $\mathrm{kJ} ; Q_{\gamma}$ is the heat input per kilogram fuel, kJ.

\subsubsection{Key parameters of the furnace}

Bed temperature is one of key parameters of the suspension-floating-circulating fluidized combustion system. The designed temperature should avoid grey softening and coking, improve the combustion efficiency, and reduce the emissions of fly ash carbon and $\mathrm{N}_{2} \mathrm{O}$. In addition, the slurry is difficult to burn and volatilize, so the bed temperature is designed to be $900-960{ }^{\circ} \mathrm{C}$.

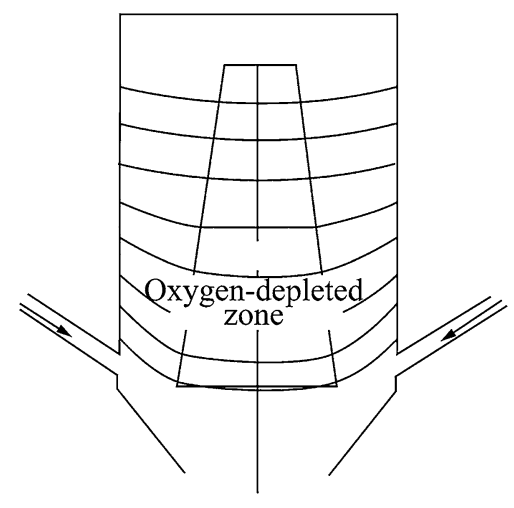

Fig. 5 Oxygen-depleted zone

The furnace heat transfer coefficient (Jiang and Xiao 2009) is estimated by this formula.

$k=k_{0} \alpha^{A} T^{B}$

where, $k$ is the heat transfer coefficient, $\mathrm{kW} / \mathrm{m}^{2} ; k_{0}$ is the ratio; $A$ and $B$ are constant coefficients; $\alpha$ is the concentration of suspended particles, $\mathrm{kg} / \mathrm{m}^{3}$; and $T$ is the average temperature of the furnace. The material concentration is the biggest factor affecting heat transfer coefficient of the heating surface of the indoor combustion, higher materials concentration makes higher heat transfer coefficient.

Correct choice of the furnace fluidization air speed is also important to slurry combustion. The fluidization air speed is determined generally by fluidized bed cold experiment.

\subsubsection{Secondary air system design}

If the fuel and air is not mixed evenly, it can affect the thermal efficiency and the combustion efficiency of the boiler. In the furnace combustion center of the traditional CFBB, there is an oxygen-depleted zone (Jiang and Xiao 2009), as shown in Fig. 5. The oxygen-depleted zone is very detrimental to slurry suspension combustion. Under the premise of guaranteed boiler pressure, as shown in Fig. 6, the multilevel asymmetry design of secondary air can carry oxygen to the furnace during the slurry blocks fall down in the process of S-shaped rotation. This design can avoid the oxygen-depleted zone and extend the falling time and path of slime to ensure the combustion efficiency and desulfurization efficiency (Gunka and Pyshyev 2014).

\subsection{Steam temperature regulated system}

The steam temperature of the boiler will affect the safety and economy of the whole production process directly. Steam temperature regulated system of the boiler is 


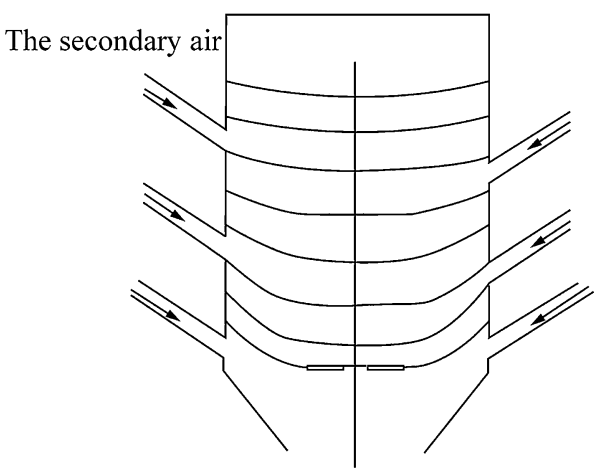

Fig. 6 Asymmetry secondary air

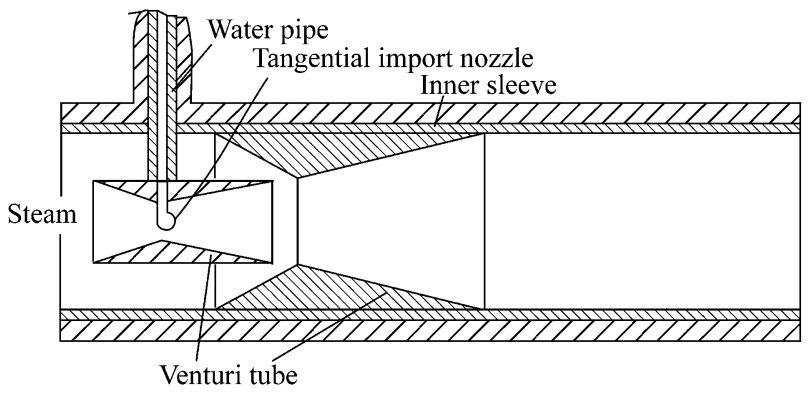

Fig. 7 The structure of new desuperheater

composed of a three-level superheater and two-level desuperheater.

When slurry is burning in the furnace, the suspension combustion will make the superheater system deviated from its nominal parameters, especially the over-temperature phenomena of the platen superheater is a serious problem to boiler safty. For this reason, a new types of spray desuperheaters is devised, as shown in Fig. 7.

It consists of a steam pipe, water pipe, venturi tube, tangential import centrifugal nozzle and inner sleeve. The new type desuperheater is set before the platen superheater. It has well atomization effect and high thermal efficiency; it can realize a wide range of steam temperature regulation; and it's able to adapt to a wide range of steam loads.

\subsection{Fuel return system}

The system can improve the fuel combustion efficiency and reduce the thermal heat losses of solid fuel. It mainly includes a cyclone separator, $U$ return feeder, and fluidizing air, which are critical components to the fuel circulating. During the suspension combustion, the hightemperature fuel gas flies out of the furnace and enter the cyclone separator. The unburned fuel particles will be separated and drop into the $\mathrm{U}$ feeder, finally under the

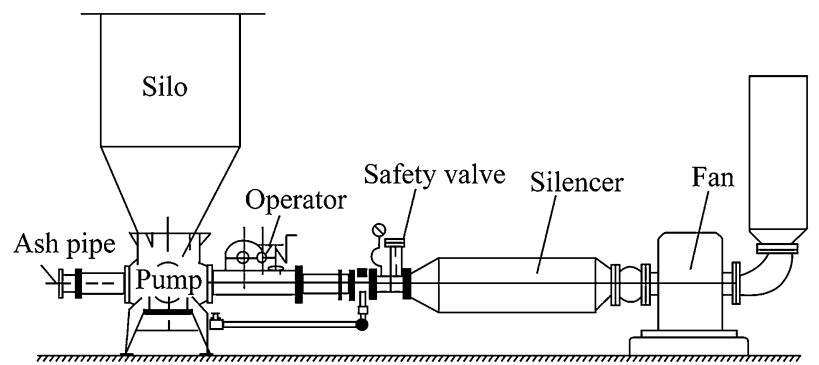

Fig. 8 The structure of material sealed pump

effect of fluidizing air they return to the furnace. If general compressed air is used to fluidize the returned fuel, the oxygen in the compressed air will easily cause the returned high-temperature fuel to burn and coke in the feeder, and that will affect the safe operation of the boiler. So steam is used to replace compressed air in the new technology ( $\mathrm{Li}$ and Xiao 2005). The steam velocity $\mathrm{V}_{\mathrm{lj}}$ can be calculated as follows.

$V_{\mathrm{lj}}=0.0882 A_{\mathrm{r}}^{0.528}\left(v_{\mathrm{y}} / D_{\mathrm{dl}}\right) \mathrm{m} / \mathrm{s}$

where, $A_{\mathrm{r}}=g D_{\mathrm{dl}}^{3} / v_{\mathrm{y}}^{2}\left({ }^{\prime} y_{\mathrm{g}}-{ }^{\prime} y_{\mathrm{y}}\right) /{ }^{\prime} y_{\mathrm{y}}$ is the rule of Archimedes; $v_{\mathrm{y}}$ is the coefficient of kinematic viscosity of steam, $\mathrm{m} / \mathrm{s}^{2} ;{ }^{\prime} y_{\mathrm{g}}$ is the true specific gravity of solid particle, $\mathrm{kg} / \mathrm{m}^{3}$; ' $y_{\mathrm{y}}$ is the portion of steam, $\mathrm{kg} / \mathrm{m}^{3} ; D_{\mathrm{dl}}$ is the average diameter of the solid particle, $\mathrm{m} ; g$ is the acceleration of gravity, $\mathrm{m} / \mathrm{s}^{2}$.

The limestone $\left(\mathrm{CaCO}_{3}\right)$ as desulfurizer under the high temperature will decompose as follows:

$\mathrm{CaCO}_{3} \rightarrow \mathrm{CaO}+\mathrm{CO}_{2}$

Then the generated $\mathrm{CaO}$ meet the $\mathrm{H}_{2} \mathrm{O}$ react in the steam as follows:

$\mathrm{CaO}+\mathrm{H}_{2} \mathrm{O} \rightarrow \mathrm{Ca}(\mathrm{OH})_{2}$

Under the same $\mathrm{Ca} / \mathrm{S}$ molar ratio, the desulfurization efficiency of $\mathrm{Ca}(\mathrm{OH})_{2}$ is higher than that of $\mathrm{CaCO}_{3}$. Therefore using steam instead of compressed air cannot only avoid the secondary combustion of the returned fuel but also increase significantly the desulfurization efficiency.

\subsection{Ash conveying system}

After the slurry burn-out, a large amount of fine ash will be produced. If the ash is not discharged in time, it will affect the electrostatic precipitator and pollute the environment (Wang et al. 2014). In many CFBB bins pumps are used to convey ash. It shows large power consumption, serious wear and tear. To avoid these problems, the LFB pump with low pressure air is chosen in this new system, and its structure is shown in Fig. 8. 
Table 1 Design parameters of the boiler

\begin{tabular}{llcl}
\hline No. & Name & Units & Value \\
\hline 1 & Rated steam temperature & ${ }^{\circ} \mathrm{C}$ & 540 \\
2 & Rated steam pressure & $\mathrm{MPa}$ & 9.8 \\
3 & Rated capacity & $\mathrm{t} / \mathrm{h}$ & 130 \\
4 & Maximum evaporation & $\mathrm{t} / \mathrm{h}$ & 143 \\
5 & Feed-water temperature & ${ }^{\circ} \mathrm{C}$ & 215 \\
6 & Boiler flue gas temperature & ${ }^{\circ} \mathrm{C}$ & 143 \\
7 & Thermal efficiency & $\%$ & 89.58 \\
8 & Coal slurry consumption & $\mathrm{kg} / \mathrm{h}$ & 28,528 \\
9 & Limestone consumption & $\mathrm{kg} / \mathrm{s}$ & 1.24 \\
10 & Limestone particle size & $\mathrm{mm}$ & $\leq 2$ \\
11 & Hot air temperature & ${ }^{\circ} \mathrm{C}$ & 300 \\
12 & Cold air temperature & ${ }^{\circ} \mathrm{C}$ & 30 \\
13 & Flow ratio of pri. and 2 nd air & & $50: 50$ \\
14 & Superheater steam temperature & ${ }^{\circ} \mathrm{C}$ & 520 \\
15 & Combustion chamber temperature & ${ }^{\circ} \mathrm{C}$ & 960 \\
16 & Blowdown rate & $\%$ & $\leq 2$ \\
17 & Circulation ratio & & $15-20$ \\
18 & Desulphurization efficiency & $\%$ & $\geq 85$ \\
19 & Calcium sulfur ratio & & $1.5-2$ \\
20 & Fly ash of the boiler & $\mathrm{kg} / \mathrm{s}$ & 8.4 \\
21 & Design boiler efficiency & 93.24 \\
\hline & & &
\end{tabular}

The energy of the LFB pump comes from the fan and the potential energy of the silo. Low pressure air goes through the duct and pump into the diffusion chamber. When high speed air goes through the pump, it forms negative pressure between the nozzle and the diffusion chamber, the gasified ash by nozzle is sucked into the ash pipe.

\section{$3130 \mathrm{t} / \mathrm{h}$ suspension-floating-circulating fluidized bed boiler}

\subsection{The design parameters of the boiler}

The type of CFBB used in the paper is TG130/9.8-M. It is characterized by high temperature and pressure, single drum tap, single furnace, natural circulation, and full steel frame layout. It is equipped with two sets of $30 \mathrm{MW}$ steam turbine generator. Its original fuel is bituminous coal or anthracite. The boiler is retrofitted to burn slurry, and its main design parameters are shown in Table 1.

\subsection{The fuel of boiler}

The parameters of the desired fuel for the boiler are shown in Table 2.

The coal slurry with a moisture content of $25 \%-30 \%$ and size of particles of less than $3 \mathrm{~mm}$ from the Baizhuang mine is used to show the new technology. The test data of Baizhuang coal slurry is also shown in Table 2. Detailed analytical data of the design and test of coal slurry shows that the coal slurry from the Baizhuang mine can be used as the boiler fuel. The blending proportion of slurry is $94 \%$ in boiler fuel.

\subsection{Selection of bed material}

The selection of density and size distribution of inert bed material directly affects the fluidization quality of the boiler, and further affects the characteristics of combustion and heat transfer. Considering the different density fluidized bed and operating cost, the coal gangue in Baizhang mine is selected as the bed material. The proximate analysis of this coal gangue is shown in Table 3.

Coal gangue is waste in coal preparation process and washing coal, the diameter of particles is generally $0-10 \mathrm{~mm}$, the density is $1.69 \mathrm{~g} / \mathrm{cm}^{3}$, and deformation temperature is $1350{ }^{\circ} \mathrm{C}$. The size distribution of fresh bed material is shown in Table 4.

Using coal gangue as bed material has the following advantages: firstly, the hardness of coal gangue is relatively low, so it can effectively reduce the wear and tear of the boiler; secondly, after coal gangue is added as bed material, some particles will participate in the combustion to generate heat, so as to improve the combustion efficiency of the boiler; thirdly, it can make full use of waste materials.

\subsection{Coal slurry conveying system}

As shown in Fig. 9, the coal slurry conveying system of the $130 \mathrm{t} / \mathrm{h}$ boiler is used to transport slurry with concentration of $70 \%-75 \%$ from the Baizhuang mine. The transport distance is $300 \mathrm{~m}$ in the boiler system.

Table 2 Proximate and elementary analysis of coal slurry

\begin{tabular}{|c|c|c|c|c|c|c|c|c|c|c|}
\hline \multirow[t]{2}{*}{ Item } & \multicolumn{4}{|c|}{ Proximate analysis } & \multirow[t]{2}{*}{$Q_{\text {net,ar }}(\mathrm{kJ} / \mathrm{kg})$} & \multicolumn{5}{|c|}{ Elementary analysis } \\
\hline & $M_{\mathrm{ad}}(\%)$ & $A_{\mathrm{ad}}(\%)$ & $V_{\mathrm{ad}}(\%)$ & $F C_{\text {ad }}(\%)$ & & $\mathrm{C}_{\mathrm{ar}}(\%)$ & $\mathrm{H}_{\mathrm{ar}}(\%)$ & $\mathrm{N}_{\mathrm{ar}}(\%)$ & $\mathrm{S}_{\mathrm{t}, \mathrm{ar}}(\%)$ & $\mathrm{O}_{\mathrm{ar}}(\%)$ \\
\hline Design slurry & 34 & 18.35 & 19.36 & 32.16 & 17,800 & 39.28 & 2.60 & 0.71 & 0.27 & 5.14 \\
\hline Tested slurry & 35.33 & 11.53 & 20.25 & 34.67 & 18,423 & 43.20 & 2.53 & 0.95 & 0.38 & 3.35 \\
\hline
\end{tabular}


Table 3 Proximate analysis of coal gangue

\begin{tabular}{llllll}
\hline Item & $M_{\mathrm{ad}}(\%)$ & $A_{\mathrm{ad}}(\%)$ & $\mathrm{S}_{\mathrm{t}, \mathrm{ar}}(\%)$ & $Q_{\text {net,ar }}(\mathrm{MJ} / \mathrm{kg})$ & $F C_{\mathrm{ad}}(\%)$ \\
\hline Gangue & 3 & 80 & 0.15 & 5.3 & 17 \\
\hline
\end{tabular}

Table 4 Size distribution of bed material

\begin{tabular}{lllc}
\hline No. & $\begin{array}{l}\text { Aperture of screen } \\
(\mathrm{mm})\end{array}$ & $\begin{array}{l}\text { Average } \\
\text { diameter }(\mathrm{mm})\end{array}$ & $\begin{array}{l}\text { Percentage } \\
(\%)\end{array}$ \\
\hline 1 & $2-4$ & 2 & 5 \\
2 & $4-6$ & 4 & 30 \\
3 & $6-8$ & 6 & 60 \\
4 & $8-10$ & 8 & 5 \\
\hline
\end{tabular}

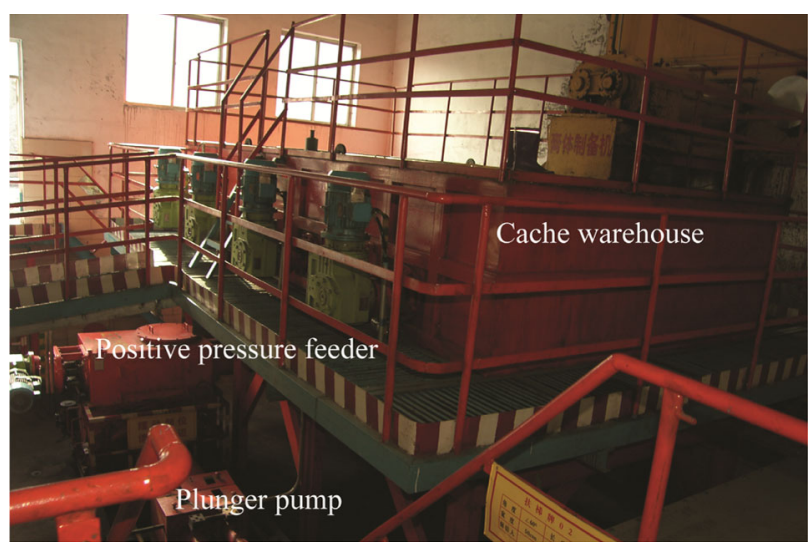

Fig. 9 Coal slurry conveying equipment

According to the rheological properties of slurry experiment, the reynolds number $R_{e}$ is 2100 , the desired flow of the boiler $Q$ is $7.92 \mathrm{~kg} / \mathrm{s}$, the density of coal slurry $\rho$ is $1430 \mathrm{~kg} / \mathrm{m}^{3}$, the rheological index $\mathrm{n}$ approaches to 1 , the power-law viscosity coefficient $\eta$ is 0.2011 , the maximum pressure of the hydraulic system is set to $31.5 \mathrm{MPa}$, and the pipeline pressure is set to $18 \mathrm{MPa}$. Then the conveying pipeline diameter $D$ is $291 \mathrm{~mm}$, the maximum flow rate of the system is set to $30 \mathrm{~m}^{3} / \mathrm{h}$, and the maximum conveying distance is longer than $500 \mathrm{~m}$.

\subsection{Bed-material conveying system}

The bed-material conveying system guaranteeing the layer height and pressure of the coal gangue, makes the boiler maintain a good circulating fluidized state and effectively avoids coking after slurry falling on the $\mathrm{CFB}$, and then ensures the safe operation of the boiler.

The cold test of CFB shows that the layer height of the coal gangue on the CFB should be between $550 \mathrm{~mm}$ and $600 \mathrm{~mm}$, and the differential pressure of the gangue layers should be between $6.8 \mathrm{kPa}$ and $7.2 \mathrm{kPa}$. A bed-material conveying system with a wind-seal device invented by the authors is designed to convey bed material safely, as shown in Fig. 10, sealed pipe is $100 \mathrm{~mm}$ in diameter, sealed wind flow is about $1300 \mathrm{~m}^{3} / \mathrm{min}$, sealed air pressure is not less than $7.5 \mathrm{kPa}$.

\subsection{Steam temperature regulated system}

In the process of boiler operation, the phenomenon of overtemperature at the platen superheater is very serious in the steam temperature regulated system. The safe inlet temperature of platen superheater must be less than $400{ }^{\circ} \mathrm{C}$. The platen superheater temperature is greatly influenced by the flue gas temperature at furnace exit. The flue gas temperature at furnace exit is mainly affected by the blending proportion of slurry. The relation between the flue gas temperature at furnace exit and the blending proportion of slurry is shown in Fig. 11. So the higher the blending proportion of slurry is, the bigger the temperature value of the platen superheater will be.

To meet a high blending proportion of slurry and improve the boiler thermal efficiency, a three-level superheater and a two-level desuperheater of the steam temperature regulated system are designed as follows.

The spray desuperheater is divided into two levels. The level 1 is installed at the entrance of the platen superheater. The level 2 is installed in the middle of the hot and cold section of the high-temperature superheater.

The level 1 desuperheater is designed as follows: Two level 1 desuperheaters with a water flow of $6.94 \mathrm{t} / \mathrm{h}$, are used in series to increase the quantity of cooling water; and a new desuperheater is used to improve the efficiency of heat exchange. Combining these two methods can keep the inlet temperature of the platen superheater less than $400{ }^{\circ} \mathrm{C}$.

\subsection{Return fuel system}

The return fuel system uses the steam cooled cyclone separator and a $U$ return feeder as shown in Fig. 12. They are used to ensure the fuel to circulate and reduce the unburned fuel in the flue gas and increase the combustion efficiency. The main performance requirements of return fuel system are that the efficiency of the separator is less than $99 \%$, and the fluidization air pressure is not higher than $1.2 \mathrm{MPa}$.

At the furnace exit we arrange two steam-cooled cyclone separators with $\varnothing 4400 \mathrm{~mm}$ in diameter. The cyclone separator takes tangential air inlet method to ensure the separation efficiency is no less than $99.5 \%$.

By analyzing all levels steam of the turbine, it can be discovered that the third level whose pressure is about 1.0 MPa and temperature is above $300{ }^{\circ} \mathrm{C}$, simultaneously meets the requirements of pressure and temperature. 


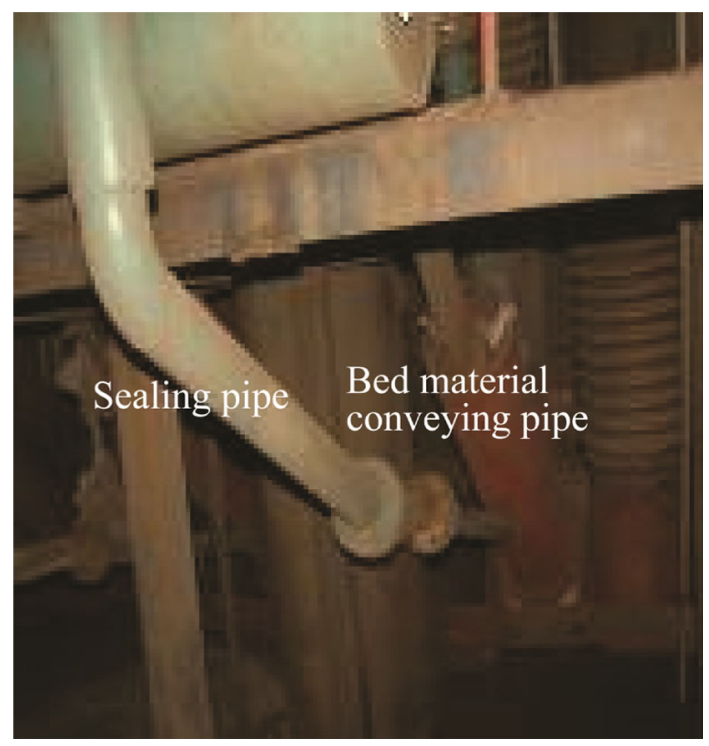

Fig. 10 Wind-seal equipment

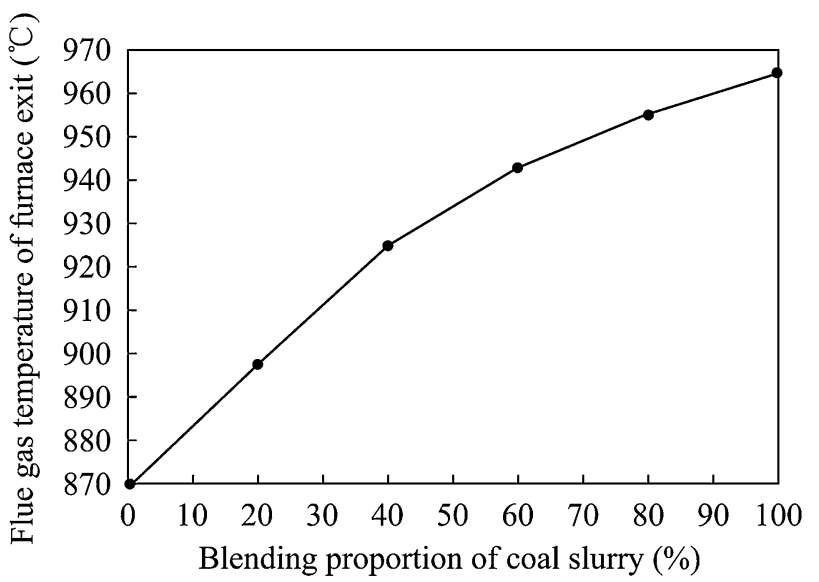

Fig. 11 Relation between flue gas temperature of furnace exit and blending proportion of coal slurry

Therefore, the third level is used to instead of compressed air as the fluidization dynamics of return fuel.

\subsection{Ash conveying system}

The system adopts a novel pneumatic pump device LFB150 to convey ash. Its operating parameters are shown in Table 5. The conveying pressure is between $0.04 \mathrm{MPa}$ and $0.1 \mathrm{MPa}$, and the conveying pipe is $\varnothing 180 \mathrm{~mm} \times 8 \mathrm{~mm}$ in diameter. Figure 13 shows the application of the LFB150.

\section{Combustion efficiency test}

In order to investigate the overall performance of the boiler, and analyze its technical characteristics, experiments under different load conditions have been carried out. The

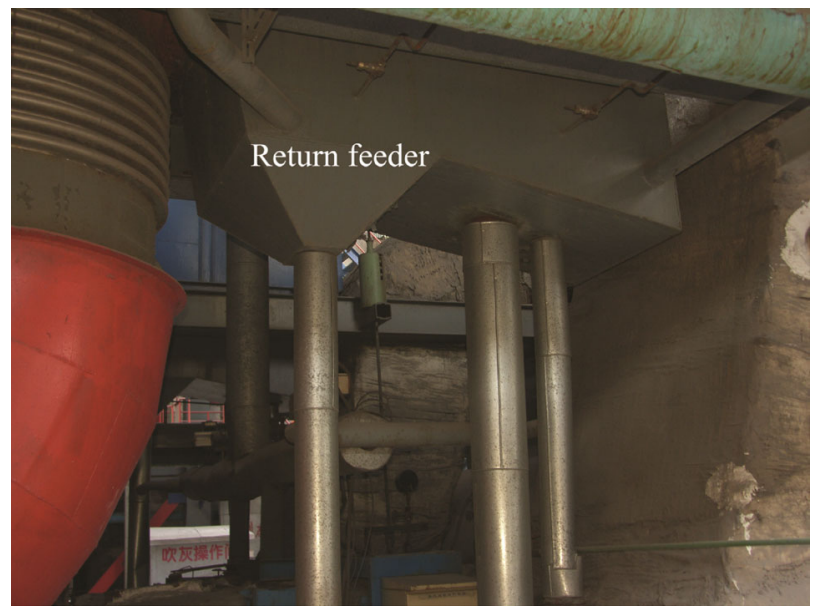

Fig. 12 The U return feeder

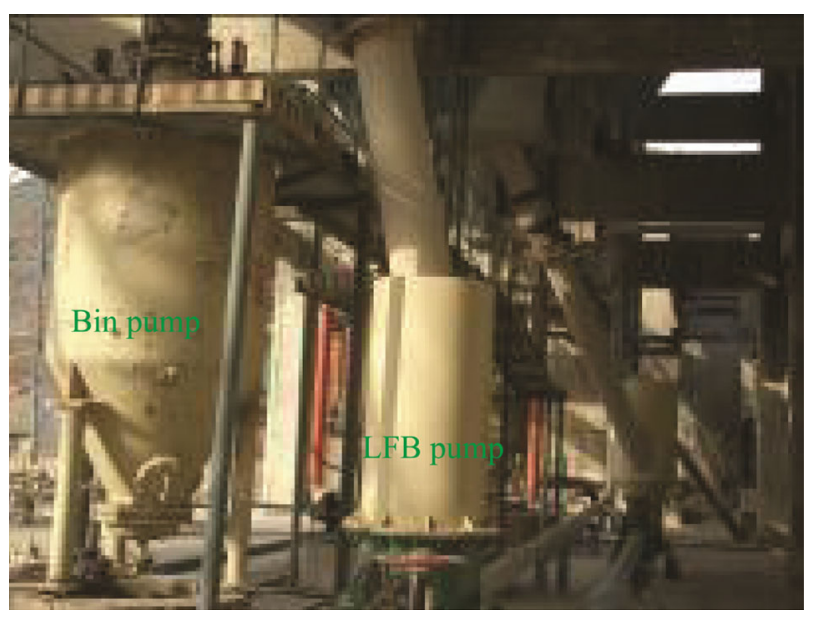

Fig. 13 The application of the material sealing pump

criterions used are the standards of the People's Republic of China: (1) "Test code of thermal performance for Industrial boiler" (GB/T10180-2003), (2) "Monitoring and testing method for energy saving of industrial boiler" (GB/ T15317-94), (3) "General specification for industrial boiler" (ZB/T10099-1999), (4) "The determination of particulates and sampling methods of gaseous pollutants from exhaust gas of stationary source" (GB/T16157-96) and (5)

Table 5 LFB pump process parameters

\begin{tabular}{ll}
\hline Name & LFB150 \\
\hline Conveying capacity & $10-25 \mathrm{~m}^{3} / \mathrm{h}$ \\
Air consumption & $10-30 \mathrm{~m}^{3} / \mathrm{min}$ \\
Airpressure requirements & $0.03-0.1 \mathrm{MPa}$ \\
Outlet pipe diameter & $150 \mathrm{~mm}$ \\
Roots blower & FSR $200: Q_{\mathrm{s}}=35.36 \mathrm{~m}^{3} / \mathrm{min}$ \\
Conveying pipe & $\varnothing 194 \mathrm{~mm} \times 6 \mathrm{~mm}$, a total of $70 \mathrm{~m}$ \\
\hline
\end{tabular}




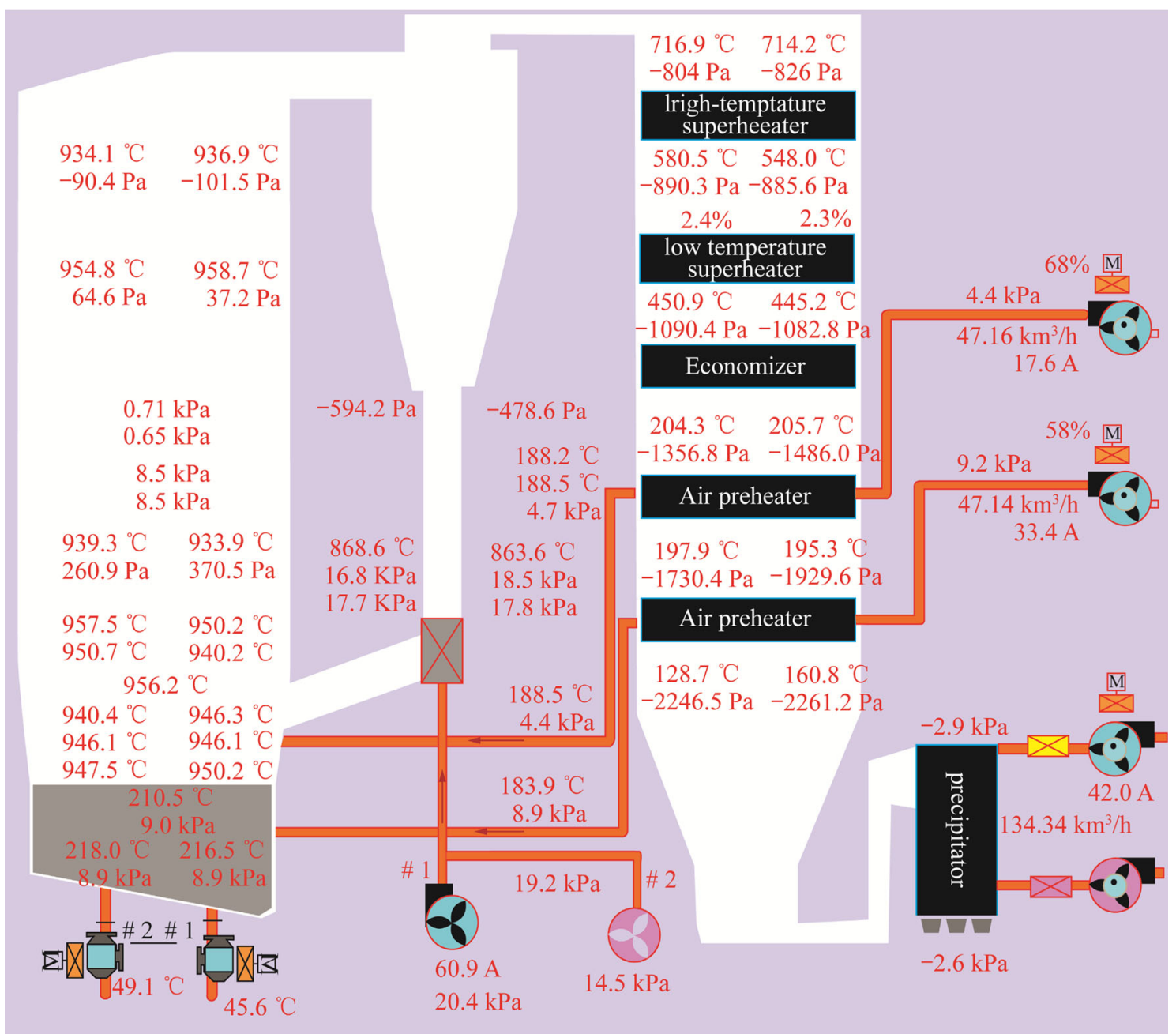

Fig. 14 Operating parameters of slurry boiler

"Measurement method of smoke and dust emission from boiler"(GB5468-91), etc.

The two-stage ignition method is adopted during the boiler test process; when the boiler load reaches $40 \%-$ $50 \%$ of the rated value, the temperature of smoke around the furnace outlet is $890-900{ }^{\circ} \mathrm{C}$, the amount of slurry can be increase gradually. In accordance with the compress air parameters the throttle is adjusted to achieve the required load to ensure slurry stable combustion, then the startup process ends. During the boiler operating, the furnace pressure differential maintains between $500 \mathrm{~Pa}$ and $1000 \mathrm{~Pa}$ and the material layer pressure differential maintains between 7000 and $9000 \mathrm{~Pa}$.

The ignition point of slurry is 1.66-1.87 times as high as that of the same kind of coal powder. The water evaporation absorbing heat makes the ignition time delayed significantly. The supply of compress air is the key factor to reduce the slurry ignition. The primary air with the $26 \mathrm{~m} / \mathrm{s}$ speed adjusts the fluidization, furnace temperature and material layer pressure differential. When the load of the furnace reaches $50 \mathrm{t} / \mathrm{h}$, the secondary air with a speed of $55 \mathrm{~m} / \mathrm{s}$ is adopted to replenish oxygen. When the boiler load reaches the rated load, the ratio of primary air to secondary air is about 5:5.

The monitoring results of the boiler operating are shown in Fig. 14, the thermal efficiency parameters of the boiler are shown in Table 6 , and the boiler emissions test results are shown in Table 7.

From the testing results of the boiler, as shown in Fig. 14 and Table 6, it can be seen that all the operating parameters meet the requirements of design during boiler operation. The boiler has realized $89.83 \%$ thermal efficiency, $96.24 \%$ combustion efficiency, and $94 \%$ the blending proportion of slurry.

As shown in Table 7, the emission of $\mathrm{SO}_{2}$ is $35.9 \mathrm{mg} /$ $\mathrm{m}^{3}$, the emission of $\mathrm{NO}_{x}$ is $74 \mathrm{mg} / \mathrm{m}^{3}$, and the Ringelmann level is 0.5 . The pollutants emissions of the boiler are in accordance with "Emission standard of air pollutants for coal-burning oil-burning gas-fired boiler" (GB13271-2001). 
Table 6 Thermal efficiency parameters of the slurry boiler

\begin{tabular}{lcl}
\hline Name & Unit & Rated test \\
\hline Carbon content in fly ash & $\%$ & 5.42 \\
Carbon content in slag & $\%$ & 2.75 \\
$\mathrm{O}_{2}$ in discharge flue & $\%$ & 7.3 \\
Discharge flue temperature & ${ }^{\circ} \mathrm{C}$ & 145 \\
Heat loss of discharge flue & $\%$ & 9.11 \\
Chemical incomplete combustion heat loss & $\%$ & 0 \\
Mechanical incomplete combustion heat loss & $\%$ & 2.76 \\
Dissipated heat loss & $\%$ & 0.82 \\
Total heat loss & $\%$ & 10.17 \\
Boiler thermal efficiency & $\%$ & 89.83 \\
Combustion efficiency & $\%$ & 96.24 \\
\hline
\end{tabular}

Table 7 Boiler emissions test

\begin{tabular}{lll}
\hline Name & Unit & Value \\
\hline Slurry moisture & $\%$ & 30 \\
Counter balance efficiency of the rated load & $\%$ & 88.46 \\
Counter balance efficiency of 110 \% rated load & $\%$ & 87.24 \\
Counter balance efficiency of 50 \% rated load & $\%$ & 86.63 \\
Ash content of combustible (rated load) & $\%$ & 5.42 \\
NOx emission concentration & $\mathrm{mg} / \mathrm{m}^{3}$ & 74 \\
$\mathrm{SO}_{2}$ emission concentration (no desulfurizer) & $\mathrm{mg} / \mathrm{m}^{3}$ & 35.9 \\
$\mathrm{Ringelmann}$ & & 0.5 \\
\hline
\end{tabular}

The suspension-floating-circulating fluidized technology of boiler has been used in the Baizhuang mine of Shandong province of China; three CFB boilers are operating currently by using the suspension-floating-circulating fluidized technology. In 2012, the quantity of burned coal slurry was $462,300 \mathrm{t}$. Until now, the boiler has been used very successful in burning steadily and operating easily.

Experience has shown that the CFBB, with a capacity higher than $130 \mathrm{t} / \mathrm{h}$, can also be retrofitted by using the suspension-floating-circulating fluidized technology, and the new proposed technology has a good development prospect.

\section{Conclusions}

A novel suspension-floating-circulating fluidized combustion technology was proposed, and applied in the 130/th CFBB. The retrofitted CFBB has solved some problems that exist in large-capacity CFBB for burning coal slurry. For example, MNS has achieved coal slurry transport that was fully enclosed, steady, long-distance and non-polluting, coal gangue as bed-material has reduced effectively the wear and tear of the boiler and improved the combustion efficiency of the boiler, the innovative sealed device has effectively reduced the pipe blockage and prolonged the life of the conveying belt, the multilevel asymmetry secondary air has provided adequate oxygen and ensured the combustion efficiency and desulfurization efficiency, two new type desuperheater before the platen superheater has realized a wide range of steam temperature regulation and keep the inlet temperature of the platen superheater less than $400{ }^{\circ} \mathrm{C}$, and the steam as fluidizing air cannot only has avoided the secondary combustion of the returned fuel but also increased significantly the desulfurization efficiency, etc.

The experiments show that the new technology has realized $94 \%$ the blending proportion of slurry, $89.83 \%$ thermal efficiency, and $96.24 \%$ combustion efficiency. So the new technology provided an effective method to largescale application of the slurry.

Acknowledgments The study is supported by the China-Africa international cooperation projects (2012DFG71060), the National Science and Technology Support Program in China (2012BAB13B04), South African National Research Foundation (78673).

Open Access This article is distributed under the terms of the Creative Commons Attribution 4.0 International License (http://crea tivecommons.org/licenses/by/4.0/), which permits unrestricted use, distribution, and reproduction in any medium, provided you give appropriate credit to the original author(s) and the source, provide a link to the Creative Commons license, and indicate if changes were made.

\section{References}

Bo Y, Huang ZY, Huang QX, Zhang YW, Zhou JH, Cen KF (2013) Combustion characteristics of coal-water slurry in a slag-tap vertical cyclone furnace through digital imaging. Energy Fuels 27(6):3427-3437

Cao XZ, Zhao WD, Liu JZ, Sun JF, Zhou JH, Cen KF (2009) A thermogravimetry investigation on the combustibility of coalslime water slurry. J China Coal Soc 34(10):1394-1399

Chen LY, Duan YF, Zhao CS, Yang LG (2009) Rheological behavior and wall slip of concentrated coal water slurry in pipe flows. Chem Eng Process 48(7):1241-1248

Cheng J, Zhou JH, Huang ZY, Liu JZ, Yang WJ, Cen KF (2008) Design and combustion of a $130 \mathrm{t} / \mathrm{h}$ coal washing sludge and water mixture-fired boiler with high steam temperature and pressure. J. Power Eng 28:367-376

Chi Y, Jiang XG, Ni MJ, Yang JL, Yan JH, Huang GQ, Li XD, Cen KF (2001) Study on co-firing process of coal-washery-sludge and coal-washery-rejects in fluidized beds. J China Coal Soc 26(2):204-208

Daviault SG, Ramadan OB, Matida EA, Hughes PM, Hughes R (2012) Atomization performance of petroleum coke and coal water slurries from a twin fluid atomizer, Daviault. Fuel 98:83-193

Gagarin SG, Gyul'maliev AM (2009) Theoretical principles of use of coal fractions with different densities for combustion. Solid Fuel Chem 43(1):17-24 
Gunka V, Pyshyev S (2014) Lignite oxidative desulphurization. Int J Coal Sci Technol 1(1):62-69

Jakobs T, Djordjevic N, Fleck S, Mancini M, Weber R, Kolb T (2012) Gasification of high viscous slurry $R \& D$ on atomization and numerical simulation. Appl Energy 93:449-456

Ji DG, Wang ZN, (2007) Research on the suspension combustion rate of coal water slurry. Progress Min Sci Safety Technol Pts A and B: $1657-1661$

Jiang MH, Xiao P (2009) Large circulating fluidized bed boiler technology. China Electric Power Press, Beijing

Li X, Xiao F (2005) The concept of using steam as substitution for HP fluid air in CFB boiler. Boiler Technol 36:10-12

Liu M, Duan YF (2009) Resistance properties of coal-water slurry flowing through local piping fittings. Exp Thermal Fluid Sci 33(5):828-837

Liu LY, Min FF, Zhang MX, Zhao Q (2012) Sliming characteristics of different density raw coal. J China Coal Soc 37(1):182-186

Lu P, Duan RL (2006) MNS coal slurry pipeline system design research. New Technol New Process 10:39-41

Ma XY, Duan YF, Liu M (2013) Atomization of petroleum-coke sludge slurry using effervescent atomizer. Exp Thermal Fluid Sci 46:131-138

Ni MJ, Li C, Fang MX, Wang QH, Luo ZY, Cen KF (2014) Research on coal staged conversion poly-generation system based on fluidized bed. Int J Coal Sci Technol 1(1):39-45
Qu ZB, Dai CH, Chen DB (2010) 440 t/h circulating fluidized bed boiler coal slurry feed equipment improvement and application. Energy Saving Environ Protect 7:38-40

Shu GP, Zhang YZ (2014) Research on the maceral characteristics of Shenhua coal and efficient and directional direct coal liquefaction technology. Int J. Coal Sci Technol 1(1):46-55

Tang XM, Yang JL, Jiang XG, Chi Y, Yan JH (2007) Rheological behavior in Xing long zhuang coal washery sludge pump system of CFB boiler. Journal of China Coal Society. 32(6):643-646

Wang H, Jiang XM, Zhang MX, Ma YF, Liu H, Wu SH (2010) A new fluidization-suspension combustion technologyfor coal water slurry. Chem Eng Process 49(10):1017-1024

Wang A, Song Q, Tu GM et al (2014) Influence of flue gas cleaning system on characteristics of PM2.5 emission from coal-fired power plants. Int J Coal Sci Technol 1:4-12

Wu M, Pan Y, Zhao GR, Hu WW, Yang Y (2009) Pressure distribution of the coal slurry in the pipeline transportation. J China Coal Soc 34(2):267-270

Yu HL, Zhang C, Liu JZ, Cen KF (2008) Experimental study of the atomizing performance of a new type of nozzle for coal water slurry. Energy Fuels 22(2):1170-1173 